\title{
Codification of Administrative Law: The US and the Union
}

\author{
Martin Shapiro*
}

\begin{abstract}
The US Administrative Procedures Act of 1946 was engendered by partisan political conflicts. Initially judicial review of administrative rule-making under the act was extremely deferent. In the course of the 1960 s and 1970s the federal courts, basing themselves upon the unchanged language of the statute, created a new body of administrative law characterised by very great demands on the agencies and very intrusive judicial review. This transformation was fuelled by partisan realignments, fear of technocracy and desire for greater transparency and popular participation in government decision-making. Because these same forces are now active in relation to the Union, it may be anticipated that similar tendencies toward a demanding procedural law of rule-making and high levels of judicial review will be felt as Union administrative law develops.
\end{abstract}

\section{Different Traditions and Institutions}

Any sort of comparison of the codification of administrative law in the US and the European Union obviously begins with the enormous differences between the two in legal tradition, historical circumstances and current situation. Yet eventually I am going to argue that the American experience of the last thirty years or so may well foreshadow current and future developments in the Union, that from what happened in the US we may be able to predict what will happen, or at least what has the potential for happening, in Europe. The beginning of this account will do full justice to the differences. As we proceed, increasing attention will be paid to alleged convergences.

In the English-speaking legal tradition we must begin with the classic late 19th century liberal view enunciated by Dicey, who held that the absence of administrative law was one of the hallmarks of the rule of law ${ }^{1}$. The rule of law required that in any dispute with one of its citizens, the state itself be treated as if it were a private party subject to the same laws and the same courts as other private parties. Continental systems of separate administrative law and administrative courts, in Dicey's view, invariably endowed the state with a special and elevated status as guardian of the public interest while individuals involved in a dispute with the state were seen as

\footnotetext{
* University of California, Berkeley.

${ }^{1}$ A. V. Dicey, Introduction to the Law of the Constitution (Macmillan, 4th ed, 1893) pp 183ff.
} 
representing only their own special interest. The preference for the state over the individual that inevitably followed was, to Dicey, one of the characteristics that distinguished the statism of the Continent from the true rule of law to be found off its coast.

The Diceyian position was far stronger in America than in the mother country. In England it was tempered by the conviction that the Crown and its ministers must have the power to govern. In the US it was exaggerated by a democratic suspicion of all government and most especially of executive or administrative government by an elite. There were, of course, many statutory and internal rules of government management. There was the ancient learning of the prerogative writs and, as we shall note later, there was a strong element of constitutional law control of administration. Until the 1930s, however, there was no separate and explicit body of administrative law, only a scattering of jurisdictionally narrow and fragmented administrative tribunals, and no courses on administrative law as such in the law schools. Indeed in the 1930s a major debate, along explicitly Diceyian lines, raged in the American Bar Association and in academic circles over whether American law should know such a thing as administrative law. Roscoe Pound, the leading American jurisprude of the early 20th century and Dean of the Harvard Law School, led the forces of opposition to such a foreign incursion.

It was the sudden, dramatic expansion in the scope and sheer size of the federal administration in Washington entailed by the New Deal that brought on this debate. This expansion also changed the terms of the debate and transformed it into a partisan conflict between the Republican and Democratic parties. The Republican party had held the Presidency throughout the 1920s and had thus appointed most of the federal judges sitting in the '30s. Massively defeated at the polls in the '30s, the Republicans looked to the judiciary to stop the New Deal juggernaut. Armed with the electoral mandate, the New Deal Democrats trumpeted not a government of laws but a government of executive or administrative discretion informed by technological expertise. Like most of the New Deal, this emphasis on technocratic government was not really new. It simply picked up an older American political movement called Progressivism. It did so, however, with such overwhelming electoral backing, in such a climate of economic emergency, and in such a time of growth of totalitarianism elsewhere, that to the enemies of the New Deal the rule of law seemed threatened.

Thus Republicans came to accept and even champion the explicit formalisation of administrative law, even with the statist implications about which Dicey had warned, because such a law promised to impose some limits on the unlimited, technocratic, government discretion that the New Deal was claiming as its electoral reward. But the Republicans championed administrative law if, and only if, it retained a key Diceyian cornerstone. Administrative law must provide that all government actions be subject to judicial review and by review in the regular courts of general jurisdiction. Of course this Diceyian virtue corresponded with the constitutional and political realities that, of the three separate and independent branches of US government, the Democrats decisively controlled two but the Republicans still maintained a strong presence in the judiciary.

Thus in the late 1930s, anti-New Deal political forces in Congress pushed for an administrative procedures act. The New Deal responded, as it often did to its enemies, by promising an even bigger and better act after a careful study conducted by its own tame bureaucrats and lawyers. A Presidential commission was established, and a bill drafted and proposed to Congress that essentially legitimated New Deal practices. By 
the late 1930s, the New Deal had lost sufficient strength in Congress to a coalition of Republicans and conservative Southern Democrats that this proposed legislation, along with much other proposed legislation, did not pass.

In 1946, just after the War, and with 1930s esprit de corps of the New Deal much diminished, an Administrative Procedures Act was passed ${ }^{2}$. It was a grand compromise of Republican and New Deal positions. It divided government action into three rough categories: adjudication, rule-making and discretion.

Where government agencies were deciding questions of the specific legal rights of individuals, government was to act in a Republican way, that is a court-like way. The agencies were to establish tribunals presided over by 'hearing officers' who were to remain agency employees but enjoy much independence. Decisions were to be made on the basis of a trial-like record and on substantial evidence in that record. There should be court-like findings and all such decisions would be subject to appeal to the regular federal courts ${ }^{3}$. In short, there should be administrative adjudications comparable to judicial trials and subject to the same kinds of judicial appeals as are judicial adjudications.

Where matters were committed by law to agency discretion, things were to be done mostly in a New Deal Democratic way. One section of the APA says that such discretion is not subject to judicial review at all ${ }^{4}$. Another says it is subject to judicial review but may be struck down by the reviewing court only if the discretionary decision is 'arbitrary and capricious's. There are no reasons giving or record or evidentiary requirements.

It is in the third category, rule-making, that the Republican-Democratic compromise is most complex and interesting. American rule-making is what the English call supplementary or delegated legislation. Constitutionally the executive branch has no decree power. Whatever power it has to make legislative rules or even internal rules of management must come to it by authorising Congressional legislation. The APA provides that in rule-making, the agency involved must give notice that it contemplates making a rule, must afford an opportunity for outsiders to comment, and must publish its rule accompanied by a 'concise and general statement of its basis and purpose'. The agency is not required to hold a hearing, nor to compile a record nor to base its rule on any quantum of evidence. But the rule is subject to judicial review both as to its lawfulness, that is whether it is in accord with the particular statute that authorises this particular rule to be made, and also as to whether it is 'arbitrary and capricious'6. Here the Republicans won on judicial review. But the Democrats succeeded, at least initially, in emasculating that review. With no record before it, and only the briefest agency explanation, it would take a particularly aggressive judge to claim that an agency of a co-equal and independent branch of government had acted like a lunatic, that is had been arbitrary and capricious. In fact in the $1940 \mathrm{~s}$ and ${ }^{\prime} 50 \mathrm{~s}$, rules almost never failed the arbitrary and capricious test.

\footnotetext{
${ }^{2}$ Much of interest about the origins and later evolution of the APA can be found in 'The Administrative Procedure Act: A Fortieth Anniversary Symposium', (1986) 72 Virginia Law Review 215-492.

35 USC Sec 706(2)(A).

45 USC Sec 701(a)(2).

55 USC Sec 706(2)(A).

65 USC Sec 706(2)(A). Whenever in the article I make reference to US federal rule-making, I am referring to 'informal rule-making' as governed by the sections of the APA cited here and in those of comparable statutes. The APA also specifies another form of rule-making, often called 'formal rule-making', for certain specific situations. This form of rule-making requires an adjudicatory style of hearing, record and judicial review. 5 USC Sec 553(c).
} 
The APA was a 'codification' in the peculiar English-speaking or perhaps only American sense of that term. It organised and recognised in a single statute a large number of previously existent governmental practices, some of which had previously been specified in scattered ways in earlier statutes or court holdings and others of which had been agency customary practice. But unlike civil law codes, the APA did not claim to be either logically or empirically complete nor even to supersede earlier legislation. The APA is a 'residual' statute. It applies only when no other federal statute specifically provides procedural rules for a particular kind of government action. Typically when Congress enacts a statute creating a new executive agency and/or creating a new federal programme, that particular statute will contain clauses establishing the procedural rules and judicial review standards for that particular agency and/or programme.

In short, nothing could appear more different from the current situation of the European Union in confronting the question of codifying administrative law than the origin and early history of the US Administrative Procedures Act. That act was considered against a legal tradition, one of whose outstanding and boasted characteristics was the absence of a distinct administrative law. The act was the product of partisan conflict between the two national political parties, and because it was the product of such a conflict, it contains a series of compromises which may make political, but no particular legal, sense. Moreover, and again because of its compromise nature, the APA leaves many matters uncertain, consigning them to further institutional development. And finally the APA is not even a code.

One other major difference between the US and Europe must be noted. Because of their long experience of constitutional judicial review, Americans almost unconsciously adopted a crucial analogy. The Constitution authorised and thus legally legitimated statute-making by Congress. Statutes authorised and thus legally legitimated rule-making by agencies. If the courts had the power to nullify whole statutes on the grounds that they conflicted with the Constitution, then obviously the courts should have the power to invalidate whole rules that conflicted with their authorising statute. The power of American courts to invalidate rules themselves, not simply the particular applications of such rules, has never been seriously at issue in the US. On this question, two traditions that may be roughly labelled Germanic and Romantic have long existed in Europe. The German tradition is one of the invalidation by administrative courts only of applications, not rules themselves ${ }^{7}$. The French, Italian and Greek Councils of State have long held that administrative regulations themselves are administrative 'acts' subject to Council declarations of legal invalidity. The Netherlands is now in the process of moving to the Romantic camp. The German situation itself seems highly unstable. The German Constitution requires that administrative regulations have a basis in statutory law. The Constitutional Court will declare unlawful regulations unconstitutional often by abstract review. Under these conditions it appears highly anomalous that German administrative courts will not invalidate a regulation as unlawful even in concrete review.

Indeed the American experience of pre-enforcement judiciary invalidation of rules themselves, rather than only their application in particular instances, may be of particular interest to Europeans given the Council's growing practice of delegating supplementary rule-making authority to the comitology process. As the Union regulatory regime matures, it seems likely that more and more of its details will have to

${ }^{7}$ See J. Schwarze, European Administrative Law (Sweet and Maxwell, 1992) p 121. 
be filled in by such delegated supplementary law-making which Americans call rulemaking.

For Americans it is natural and normal that a court may look to the lawfulness of a rule itself as well as its application in a specific case and invalidate the rule if the court finds it unlawful. In one European tradition the capacity of a court to block application of a rule in a particular case but its incapacity to invalidate the rule itself has been viewed as a cornerstone of administrative law.

One final, and perhaps most fundamental, difference between US and European traditions must be noted. While the European practice of judicial review of applications but not the rules themselves may appear to be a quintessential legal one, it is grounded in a particular set of political institutions, namely a parliamentary as opposed to a presidential system and a system of strongly disciplined parties. Where both Parliament and the ministries are controlled by a strong cabinet, judicial invalidation of delegated legislation on the grounds that the rule was in conflict with the authorising legislation usually leads to an immediate response. But the cabinet need not order the relevant ministry to write a new rule to conform to the statute. Instead it is likely to order the Parliament to amend the statute to comply with the rule. And because the government consists of a party or coalition of parties that can order its members in Parliament to vote for government legislative proposals, the Parliament will vote to amend the statute in any way the government wants. Thus judicial invalidation of rules would be an exercise in futility. The American judicial review practice has punch precisely because the American executive rarely has that kind of hair trigger control over Congress. Even when his party controls Congress, the American president cannot count on Congress to amend the statute to save an executive rule invalidated on statutory grounds by a court. Sometimes Congress will, sometimes it won't. Thus the most significant difference between US and European administrative judicial review is grounded in fundamental differences in two basic political institutions, executive-legislative relations and political parties.

Here again, however, the contrast between the US and Europe is fading and is particularly inapplicable to the Union. In many European states party discipline has weakened and/or weak coalition governments prevail, so that where a court invalidates a rule as unlawful, the government may not be able to simply order the Parliament to alter the statute to conform to the rule. Moreover in those European states where constitutional review exists, a new statute passed to cure the invalidation of a rule might itself be found unconstitutional. Thus many European judges who have the power to invalidate administrative regulations would not now view such an invalidation as an exercise in futility. Moreover the constitutional and political structures of the Union are simply not such that if the Court of Justice invalidates a piece of Union sub-legislation, something called the 'government' could then order something called the 'Parliament' to amend the statutory law to bring it into line with the administrative regulation that had been judicially invalidated. Where the European Court of Justice legally invalidates a Commission pronouncement or other sub-statutory rule or act, either that invalidation is 'constitutional' (based on a conflict found between the norm and the Union treaties) and thus final or could only be cured by the Council amending the Council-enacted norms that the Court has held failed to authorise the sub-legislation. And the Council, by its very nature, cannot be counted on to automatically back Commission or comitology sub-legislation against the Court. Thus the Court of Justice rarely if ever faces a situation in which if it were to find a Union 
administrative act in conflict with Council-enacted statutory law, the statute would automatically be changed to validate the act.

\section{New Deal Discretion and Republican Rules}

The great differences between the administrative law of the US and Europe largely lie in the realm of statics, that is of traditions of legal doctrine and legal and political institutions that stabilise law and inhibit legal change. It is in the realm of dynamics that US and European administrative law exhibit a certain degree of convergence. In a sense all administrative law, perhaps simply all law, is driven by a single core dynamic, the dialectic between rule and discretion. As we have known since Plato, general rules never quite fit all of the specific cases to which the governor seeks to apply them. Perfect justice would require not rules but perfect discretion in which those in authority responded sensitively to each particular human situation they encountered rather than mechanically applying the same set of rules to all. That perfect tool, discretion, is alas subject to the endless imperfections of the humans who employ it: partiality, corruption, arbitrariness, ignorance, illogic. Thus as Plato too noted, real political regimes must resort to rules even while recognising the appeals of discretion.

Generally speaking, administrative law shows a relatively constant movement from discretion to rule. As societies confront grave new problems, the first move is to establish new avenues of discretionary government authority to deal with them. Flexible, quick response, power always seems the best way to deal with emergencies, and societies are forever confronting new emergencies. As time passes, and the human failings of the wielders of discretion accumulate, rules come to be substituted for discretion ${ }^{8}$. The modern nation-state exhibits a pattern in which politicians endlessly seek to expand their discretion and, after each new quantum of discretion is vested in the governors, lawyers run around seeking to cabin it with new rules: new discretion to get the job done; then new rules to protect the citizens from potential abuse of the discretion. This is not to say that there is a constant reduction in the quantum of discretion and increase in the quantum of rules, a kind of constant progress toward the rechts stadt. Rather new discretions are always being created and rules are constantly running to keep up. The long elaboration of a more and more fine spun elaboration of administrative law in both the US and Europe may be only a sign that law is keeping its head above water in a sea of discretion rather than an indication that the sea is being successfully drained.

A second dynamic involves social and political responses to technology and specifically to technocracy, that is to the claim that those who know things should rule. Such a claim engenders a conflict between technocracy and democracy. Even in modern, fully developed states, the demos knows far less than many sets of technical experts. The claim that those who know, or experts, should rule is thus at odds with the claim that the people should rule.

In the United States the rival claims of democracy and technocracy long remained quite dramatically unresolved. Initially the two great political parties in the United

\footnotetext{
${ }^{8} \mathrm{I}$ believe this is an example of the autopoietic forces central to the thinking of Niklas Luhmann and his followers (see G. Teubner and A. Febbrajo (eds), State, Law and Economy As Autopoietic Systems: European Yearbook of the Sociology of Law (Guiffre, 1991-92). However, contrary to their teachings, I believe that many political and social forces do have a direct and immediate influence on law as I shall shortly argue in relation to anti-technology sentiment and demands for transparency and participation.
} 
States each took up one of the claims. The Federalists lauded technocratic government. The Democrats sang the virtues of popular rule. Their theory of bureaucracy was the 'spoils system' and 'rotation in office'. In their view each time one of the political parties won an election, some of its rank and file should take over all the offices of administration. When that party lost some subsequent election, all of its office holders should be dismissed to be replaced by rank and file members of the winning party. In this way no long-term, professional, expert bureaucracy should arise. Instead party-defined sets of the people, rotating groups of Cincinnati, should take turns in office, avoiding the estrangement of the governors and the government from the people that necessarily arose when governing became a special occupation.

Except for a few tiny islands of bureaucratic expertise, the Democratic vision was the actual practice of the United States for its first hundred years. Only very late in the 19 th century did the Progressive Movement cut across the lines of the two major political parties to call for government by experts. Progressivism led to the gradual professionalisation of bureaucracies on the British 'civil service' model. It went further, however, seeking to carve out a whole range of 'non-political' government services that should be administered by experts free of any direct control by elected politicians. The city manager, the municipal police, sanitation and health commissions, the state utilities commissions and the federal independent regulatory commissions are the products of this vision. Elements of popular control were injected but such control was to be bipartisan or unpartisan rather than through the central democratic mechanisms of party electoral competition.

In the Progressive era, from the 1890 s until the 1920 s, democratic and technocratic visions were often at war with one another. The New Deal theory of the "strong Presidency', which dominated the 1930s and '40s, resolved the conflict between democracy and technocracy - a democratic President directing a technocratic bureaucracy was to provide the solution to America's disastrous economic problems.

All of this may appear to be the very British notion of a neutral bureaucracy taking the direction of the government of the day. It was not. New Deal Democrats did not envision the Republicans ever again taking control of the White House. In the 1930s the Democratic Party did not take over an ongoing bureaucracy that had previously served the previous three Republican presidents. That old bureaucracy was simply swamped by a flood of new, young men (and a few women) attracted to Washington precisely because they believed in the New Deal and wanted to work for it. Neither they nor those who recruited them saw them as joining a neutral civil service dedicated to serving whomever got elected. These people were not joining the civil service. They were joining the New Deal. Their virtue was not neutrality but New Deal enthusiasm. Technicians they were, but technicians devoted to Mr. Roosevelt.

It is precisely for this reason that the movement for an APA, for a replacement of expert discretion by rules, arose in Republican circles in the 1930s. The APA is not primarily a Congressional response to the sudden enormous growth of discretion wielded by the executive branch. It is a Republican response to the growth of a Democratic bureaucracy. It distrusts discretion. It distrusts technocracy. But most of all it distrusts Democrats.

It is necessary to understand these partisan origins of American administrative law in order to understand why that law worked one way in the two decades immediately following the passage of the APA in 1946 and in an entirely different way in subsequent decades. When Republicans pushed for a codification of federal administrative law in the $1930 \mathrm{~s}$, in which judicial review was to be a keystone, they did 
not have to distinguish between the general propensity of judges to subordinate administrative discretion to rules and the general propensity of Republicans to rein in New Deal enthusiasms. Nor did they see the issue as one of democracy versus technocracy. In the 1930s a newly recruited New Deal bureaucracy faced a federal judiciary, most of whom had been appointed by the unbroken run of three Republican presidents in the 1920s. Judicial review would mean Republican judges constraining the discretion of Democratic bureaucrats.

Alas, the APA was not enacted until 1946. By the time serious enforcement began, the federal judiciary was dominated by Mr. Roosevelt's appointees, for Mr. Roosevelt, all by himself, had been president longer than all three of the Republican presidents of the 1920s combined. When New Deal judges faced New Deal bureaucrats, the issue was not discretion versus rule, nor democracy versus technocracy, nor Democrat versus Republican. There was no issue. New Deal judges simply could not believe that New Deal bureaucrats would do anything wrong. The dominant administrative law doctrine of the 1950s and early 1960s was that of judicial deference to administrative expertise - not only on questions of fact but on questions of law. This judicial acquiescence in technocratic government was fostered by the victories that the New Deal had won in the struggle over the APA itself.

For remember, in the crucial sphere of delegated or supplementary legislation, the APA did not require that the rule-making agency compile a record, meet any particular evidentiary standard or fully explain why it had made the rule it did. Faced with this blank wall, the courts reviewing agency rule-making had little choice but to presume, as they openly declared they did, that the agency had properly assessed the facts and interpreted the law. And New Deal judges surely believed that whatever discretion New Deal bureaucrats were wielding was being wielded in the right cause and the true faith. New Deal judges were hardly likely to say that New Deal bureaucrats had failed the APA sanity test; that is, had done something arbitrary and capricious.

The consensus between New Deal bureaucrats and New Deal judges occurs in the 1950s and early 1960s. During that time period a Republican President had served two terms. The New Deal bureaucracy had survived nearly intact, although with reduced morale and energy. The federal bench, however, experienced a substantial infusion of Republican judges. During the 1960 s the New Deal was beginning to fade into history. The alliance between New Deal administrators and New Deal judges eroded. The result was a major change in administrative law doctrine. From the complete judicial deference to administrative decision-making of the 1950s, the US moved to the extremely activist, intrusive judicial review of administrative action of the 1970s. One New Dealer could trust that another brother in the faith wielded his discretion wisely and in the public interest. When the brotherhood dissolved, judges began to demand that administrators prove to them that they had acted well.

\section{Causes of Judicial Activism: Anti-technocracy, Transparency and Participation}

Few American observers would attribute this shift from judicial passivity to judicial activism solely to the changing patterns of Republican and Democratic control over the three great branches of the US national government. In part this reluctance to focus on political parties is the result of the standard reluctance of academic lawyers 
to undermine the useful myth of judicial independence by acknowledging the role of partisan politics in judicial decision-making. But in part the search for other causes of the changes in US administrative law is well advised. First of all, in the real world, as opposed to the world imagined by many social scientists, a major change in social practice is likely to be overdetermined, the result of a number of causes acting in the same direction rather than a single cause. Secondly, the end of the New Deal consensus would certainly have engendered some level of policy disagreement between administrators and judges. But it is not inevitable and universal that such policy disagreements lead to active judicial intervention in the administrative process. We must look to a wide range of reasons why American judges did not just 'grin and bear it' in the 1970s and '80s when they disagreed with the agencies.

We can begin with broad legal traditions. As we have already noted, the tradition of activist, constitutional judicial review by the Supreme Court creates a kind of constant pressure toward activist statutory review of rules as well.

From this relatively concrete aspect of legal culture, I wish to move to a very broad aspect not even of political culture narrowly conceived but of general intellectual life. Western culture is often described as most distinguished from others by its. deep commitment to science and technology. Without questioning the depth of that commitment, it is necessary to acknowledge counter currents that sometimes trouble this ever expanding flow of science. From time to time the West as a whole, and/or particular parts of it, experience great waves of suspicion or fear of science and technology. The United States has been in the grip of such a wave since roughly the end of World War II. The atomic bomb and the Cold War showed us not the benevolent face of technology but its very real potential for ending the human race. They also showed us that our most revered scientists and technologists were not purely public-spirited, politically neutral people in white coats pursuing truths by writing on blackboards and peering into test-tubes. The new big science needed big government money and produced big weapons. Scientists and technologists began to be seen not as disinterested, but as engaged in self-interested pursuit of fame, fortune and tax dollars. Science turns into the 'military-industrial complex' denounced as early as President Eisenhower's farewell address.

This disenchantment with technology becomes merged with and increased by the anti-Viet Nam war movement. Science and technology are now napalm, helicopter gun ships and Agent Orange. The final fruition is, of course, the environmental religion that grips us today. Science and technology are killing the world.

If technology is the enemy, it must follow that technocracy, rule by technologists, is the last thing we want. We have seen that the US has always enjoyed two conflicting theories of public administration, rule by experts and rule by the people. We have seen how the New Deal reconciled the two. We have seen the New Deal consensus eroding at the very time a new wave of antitechnology sentiment is arising. By the 1960s, rule by experts was seen in the US as a grave danger because experts ceased to be seen as politically neutral, unselfish servants of the public interest under the democratic control of elected leaders. Instead experts came to be seen as simply another set of special interests each using its specialised knowledge as a political weapon wielded in pursuit of its own selfish ends, ends that were often dangerous. And these special interests were particularly dangerous because their claim to policy-making authority was that they understood things that the rest of us could not understand. Such claims were claims to be legitimate rulers beyond the control of the demos.

The reaction against technocracy took a number of forms. One was an activist 
judicial review of technocratic decision-making. That those who know about some particular thing should make the decisions about that thing is a powerful base of legitimacy in Western culture. But it was precisely that claim to legitimate governing authority that was now regarded as a menace. The need was for some countervailing legitimate governing authority. Given the traditions of an activist judiciary in the US, one available, countervailing legitimate governing authority was the judge.

Judicial expertise is not merely a rival legitimacy to science but one peculiarly appealing to the American anti-technocrats of the post-World War II era. For to be a legal expert is not only to be expert in law but also to know nothing of any of the technologies that make a modern industrial nation work. The judge had an expertise that allowed him to legitimately challenge technocrats, but it was not a technocratic expertise that would ally him to those technocrats. The judge had the clout of the expert, but the ignorance of the people. He thus became an ideal figure to reassert popular control over technocratic government. Because the technocrat functioned in a government of laws, the judge might legitimately claim the right to examine the lawfulness of technocratic decisions. But that submission of a government decision to a legal expert was also, and unavoidably, the submission of a technological decision to a lay person, a non-technologist, and thus a representative of the people. Elsewhere I have argued that as the US moved from an industrial to a post-industrial political economy, the judge moved from industrial idiot to post-industrial hero'.

This strange status of the judge as someone who could claim a share of governance on the basis of a non-technological expertise was peculiarly attractive to the arch antitechnocrats, the environmentalists. Environmentalists could not hope to achieve the destruction of the modern industrial economy. At best, they could achieve a certain remission in technology through strong doses of government regulation. Such regulation would, however, necessarily be highly technical in character. Thus it could only be implemented by technical experts. The environmentalist could only achieve his victory over technology by creating even more technocratic government. And these technocrats could not be trusted.

The initial solution of the environmentalists was to write new health, safety and environmental protection statutes containing many 'agency forcing' and 'technology forcing' provisions - that is, legal commands to implementing technocrats to get things done even when the experts claimed they couldn't or shouldn't be done. And these anti-technocrat provisions were combined in these statutes with other provisions providing for judicial review, sometimes under more rigorous standards than those of the APA, and for private rights of action. Such private rights of action meant that the same environmental activists who had pushed the regulatory legislation through Congress in the first place could then sue the technocrats if they did not implement the legislation vigorously enough. The environmentalists could solve the paradox of having to set technocrats they distrusted to regulate the technology they hated by injecting the judge as lay watchman poised to strike down technocratic pathologies ${ }^{10}$.

Thus a combination of the American legal tradition of judicial activism and a major wave of American anti-technocratic sentiment empowered judges of the 1960s and '70s to break out of the judicial passivity of the ' 40 s and ' 50 s engendered by the New Deal consensus and to begin the activist judicial review of administration hoped for by the anti-New Deal forces that had pushed for an APA in the 1930s.

\footnotetext{
${ }^{9}$ Shapiro, 'Judicial Activism', in S. M. Lipset (ed), The Third Century (Hoover Institution Press, 1979).

${ }^{10}$ See M. Shapiro, Who Guards the Guardians (University of Georgia Press, 1988) pp 80-87.
} 
All of this may seem rather cosmic, far removed from individual judges trying real cases. But remember that what we are trying to explain here is why a substantial number of those real judges moved from almost total passivity to very active intrusion in administrative policy-making in a little over a decade. Or, to put the matter differently, the wording of the APA was the same in 1960 as it was in 1970, but the judicial interpretation of that statute had changed radically. What accounts for the change?

Any comparative analysis of administrative law reveals numbers of nations with about the same statutes and doctrines of judicial review of administrative action. Yet, at any given time considerably more judicial intervention in administrative business will be found in some of those nations than in others. And as the American example shows so startlingly, in any one country levels of judicial intervention will vary widely from one time to another even when the statutes have not changed. Some forces other than narrowly legal ones must be causing those changes. In the final analysis, differences in levels of judicial activity in various nations with roughly the same law must be accounted for in terms of differing propensity of the judges to intervene - to judicial self-confidence if you like. American judges deferred to administrators in the 1950s. By the 1970s they deferred to no one. In the 1950s they openly said, who are we, as laymen, to overturn expert administrative judgments. By the 1970 s judges were saying, we are partners with administrators in administrative rule-making and indeed the senior partners with the final say. It was not the APA that had changed. Nor did the review provisions of new statutes significantly alter APA doctrine. What had changed was the judges' belief in the relative capacity of administrators and judges to make the right decisions. This change in judicial beliefs runs too startlingly parallel to broad changes in political alignments and general world view to deny the connection between the two. The judges live in the same world of Republicans and Democrats and technological angst as everybody else in Washington.

The dialectic of rule by experts and rule by the people governed not only the change in levels of judicial intervention but the substance of that intervention as well. So far we have been looking at one side of the coin. If faith in technology is lost, then faith in technocracy, rule by technologists, is also lost. And we look around to find people to guard us against the technocrats, among others the judges. We may easily transpose this negative sentiment toward technocracy into a positive sentiment toward democracy. The evils of technocratic government may be cured by a dose of democracy. More specifically, what becomes desirable is more popular participation and more transparency in bureaucratic decision-making. Transparency and participation are, of course interrelated. The public cannot participate in government decision-making unless it knows what the government is up to. And public participation necessarily renders government decision-making more transparent. Without any changes in the language of the APA, American administrative law moved from quite minimum demands for transparency and participation in the administrative enactment of supplementary legislation (rules) to almost absurdly maximum demands for transparency and participation. Changes in American administrative law faithfully reflect shifting American attitudes toward the desirable balance between government by experts and government by the people.

\section{Procedural Masks for Substantive Intervention}

There is, however, a second and more narrowly legal or institutional cause for increased judicial intervention taking the form of judicial demands for transparency 
and public participation in the administrative rule-making process. A distinctive feature of American administrative law is that it has always provided for substantive, as well as procedural, judicial review of administrative decisions. A judge may invalidate a rule because the rule-making agency has failed to follow either statutorily mandated or its own announced procedures. A judge may also invalidate a rule because it is substantively wrong or unreasonable or, at least, very wrong or very unreasonable. As we have seen, the APA provides for such invalidation if the rule is arbitrary and capricious, which appears to mean very, very unreasonable.

There is probably no Western judge who has ever been very comfortable with saying that the laws made by his fellow governors are invalid just because they are substantively bad. If the fellow governors made them, they must have thought they were good. If the judge now says they are bad, he is simply engaged in a policy disagreement with the rest of government. And there is no reason to believe that the judge's policy preferences are somehow more cosmically correct than the preferences of those with whom he is disagreeing. Indeed, in political cultures that believe that the views of those who know about something are to be preferred over those who don't, at least about the particular something at issue, there is good reason to prefer the views of the 'expert' government decision-makers to those of the judge.

For these reasons judges would generally prefer to fault the actions of their fellow governors on procedural rather than substantive grounds. Although lawyers know no technological substance, they are themselves the experts on procedure. Procedural review puts the judge on the high ground of expertise.

For similar reasons judges will prefer to rest their invalidation of rules on grounds of statutory interpretation rather than pure policy substance. It is better for a judge to say a rule fails because it is in conflict with the language of the statute authorising the rule or the intent of that statute than to say the rule fails because it is bad public policy. Here again the judge shifts the issue from one of policy in which the other fellow is expert to one of interpreting laws, where again the judge holds the high ground of expertise.

Besides these general considerations, we have already noted the peculiarly American one - that because of the 'arbitrary and capricious' language of the APA, an American judge would have to call the rule-making agency a lunatic in order to strike down a rule on substantive grounds. Even after the New Deal coalition broke down, most American judges preferred to avoid such rudeness.

The result was that when American judges jumped to a high level of intervention, they sought to avoid pure substantive review. On the other hand, pure procedural review would not have wholly served the judges' purposes for two reasons. First in the crucial area of rule-making, we have already noted that the APA imposed only very rudimentary procedures on the agencies. Secondly, after a court has struck down an agency's rules a few times on narrowly procedural grounds, a technocratic agency will learn how to fix its formal procedures while persisting in making rules whose substance is dictated by the preferences of the experts. Procedural judicial review ultimately may not so much check technocratic government as perfect it, disguising its self-serving policies in an impeccable procedural song and dance.

So American judges moved in what might be called a meta-procedural direction. Very infrequently they engaged in pure substantive review, simply declaring that an agency-made rule was so unreasonable as to be arbitrary and capricious. More frequently they disguised substantive review in a finding that the rule at issue violated the intent of the authorising statute. Whenever they could, the judges expressed their 
distaste for a rule by finding a purely procedural error. But the central thrust of the new American administrative law is found in a whole set of judicial demands that agency rule-making processes meet standards of total transparency, complete participation and, ultimately, perfect rationality ${ }^{11}$.

Such a set of judicial demands is not quite as confrontational as are judicial findings that agency rules themselves are simply wrong. What American courts usually say to the agency is not 'We reject this rule because it is wrong.' Instead they say 'We reject this rule because the decision-making process you employed in reaching it was not sufficiently open to public scrutiny, and/or was not adequately responsive to the various non-governmental groups and individuals who sought to participate in it, and/or did not exhibit sufficient thoroughness on your part in examining all the relevant facts, alternative policies and potential costs and benefits.' Such a judicial response does not quite say 'the rule is invalid because it is stupid'. In theory at least, the reviewing court might subsequently validate exactly the same rule it has now invalidated if the agency again arrived at the same rule but after going through the rule-making process again in a more perfect way. In that sense the court's veto is suspensive rather than absolute as it is when the court invalidates a rule on the grounds that it is substantively unreasonable or is in conflict with its authorising statute. But it would be foolish to treat such a veto as 'merely' suspensive. Precisely because this variety of judicial veto demands that the agencies engage in more and more perfect decision-making processes, it demands that each repetition of such processes be more and more costly in terms of agency decisional resources. The more participatory, transparent and rational an agency decision process must be, the longer it is going to take and the more agency effort has to be expended. When a court exercises this kind of suspensive veto, it dooms the agency to months, or even years, of new exhaustive effort to achieve a new version of a rule on which the agency has just spent months, or even years, of exhaustive effort. If the vetoing judges express even a hint of distaste for the substance of the rule the court is overtly rejecting on meta-procedural grounds, it will be a brave agency indeed that will bring exactly the same rule back to court again after a second long, hard rule-making process. To do so creates the risk of being told by the judges to do the whole thing over yet again. For no rule-making process is ever so perfect that the judges cannot find something wrong with it, particularly if they don't like the substance of the rule that has emerged.

Thus major changes in American party politics, diffuse changes in American response to technology and technocracy, increased allegiance to democratic ideals of public participation and transparency in public policy-making, and more narrowly focused dynamics of administrative law and judicial self-perception and strategy have combined to create a new American administrative law under the umbrella of an APA whose wording has not changed.

\section{The New Administrative Law and Judicial Review}

It would take too long to provide even an outline of the development of this new

${ }^{11}$ Compare M. Shapiro, op cit $\mathrm{n} 11$ with C. Sunstein, After the Rights Revolution (Harvard University Press, 1990) and C. Edley, Administrative Law: Rethinking Administrative Control of Bureaucracy (Harvard University Press, 1990). 
jurisprudence, and such outlines are available elsewhere ${ }^{12}$. A brief summary is possible. It will be recalled that the APA provisions on rule-making required notice, agency acceptance of comments from the public, and a concise and general statement of the basis and purpose of the rule. The agency was not required to create a record. The judicial review standard was one allowing the agency the broadest leeway. Judges were to strike down only rules that were so wrong they could be called arbitrary and capricious.

Working from these statutory provisions the US Courts of Appeals and particularly the Court of Appeals for the D.C. Circuit invented a whole new administrative law doctrine. Indeed they invented a new language which they used in preference to that of the statute. The courts insisted that rules be the product of 'dialogue' and 'reasoned elaboration' and that the courts and the agencies were engaged in a rule-making 'partnership'. The judge invented a 'rule-making record' requirement that is quite contrary to the deliberate omission of such a requirement in the APA. The statement to accompany the rule is no longer concise or general, nor will a simple one-line notice that the agency is considering making a rule on a particular subject suffice. The agency's notices, rule-making record and statement of basis and purpose considered together must now show that at every step the agency has made known to the public the data and policy considerations shaping its rule-drafting decisions, has responded to every question and suggestion raised by the various interests concerned with the proposed rule and has demonstrated that, even on issues about which private parties have not raised objections or queries, it has considered every relevant fact and policy alternative. Far from having to demonstrate only that it has not been arbitrary and capricious, the agency must persuade the court that it has made the best rule that it possibly could.

The rule-making process, which the APA intended to be quick, informal and largely insulated from judicial review, is now incredibly slow, formal and judicially supervised. Agencies spend much of their effort trying to make their rules judicial review proof. Rule-making has become so tendentious that the agencies are now seeking ways to make policy without having to make a rule. On the positive side, agency rule-making processes have become about as transparent and participatory as they can be. Agency work product is far more careful and complete than it once was. Far more attention is now paid to unanticipated consequences, policy coordination, cross-cutting policy considerations, the distribution and disparities of costs and benefits among those on whom the rule has an impact and the range of alternative regulatory steps that might achieve more benefits at lower costs. In short, the rule-making process is far more cumbersome but also far more rational than it once was.

While I have stressed that these changes occurred by judicial fiat under an APA whose words had not changed, I do not wish to suggest that the courts acted in defiance of Congress in making these changes. The stream of Congressional health,

12 The classic article is Stewart, 'The Reformation of American Administrative Law', (1975) 88 Harvard Law Rev. 1667-1813. See also M. Shapiro, Who Guards the Guardians: Judicial Control of Administration (University of Georgia Press, 1988). K. C. Davis, Administrative Law Treatise (K. C. Davis, multiple volumes, frequently supplemented) provides exhaustive accounts of the changes. The current state of developments can be most easily seen in any of the one volume treatises such as B. Schwartz, Administrative Law (Little Brown) which appears frequently in new editions or case books such as $\mathrm{G}$. Robinson, E. Gellhorn and H. Bruff, Administrative Law (West Publishing Co.) which appear frequently in new editions and are supplemented annually. P. Schuck, Foundations of Administrative Law (Oxford, 1994) is a recent collection of leading articles on the developments described here. 
safety and environmental statutes that flowed in the late 1960s, '70s and ' 80 s gave many indications that Congress had noted and approved what the courts were doing. My basic point is not that courts acted idiosyncratically. Quite the contrary, courts were responding to the same anti-technocratic, democratic themes of participation and transparency that were influencing all of American politics during this period and were seeking to exercise the lay public control over bureaucrats that everyone desired.

\section{Comparison With Europe}

All of this may seem a very, very long wind-up before trying to relate American to European experience. The long wind-up, however, allows me to be quite brief in attacking the European aspect of the subject. We can quickly say that the European Union now exhibits the following characteristics that are comparable to the American experience of the last few decades.

First, APA judicial review initially worked easily, in spite of its Republican, antiregulatory origins, because the judges and the bureaucrats were all New Dealers. As New Deal judges were supplemented and replaced by post-New Dealers, judicial review became more intrusive. In the European Union, the early corp of judges was largely recruited from among persons enthusiastic about the growth of the Community. The Court and the Commission were allies in the New Community Deal. Today the recruitment of Union judges draws in few European visionaries. This generation of Union judges is very post-1960s in its attitude toward the Union. The Commission and the Court of Justice are no longer natural allies.

Second, disillusion with technology is widespread in Europe as is well illustrated by the Green movement. And distrust of technocracy is even more widespread, witness the avalanche of criticism of Brussels' Eurocrats in the course of the Maastricht referenda.

Thirdly, to put the positive side, the desire for transparency and participation in government policy-making has clearly been growing in Europe as a whole. In Eastern Europe, the rejection of Communism has as one of its major features the rejection of rule by those claiming technocratic authority and a yearning for transparent government. In Western Europe the central expression of the yearning for transparency and participation has occurred in the context of the Union itself, but it can also be seen in the movements for regional autonomy in a number of Western European nations. Rule by bureaucrats far away in the capital has become a European as well as an American target. The desire for transparency in government and the desirability of nongovernmental organisations' participation in national and international policy-making are now major themes in European political discourse.

Fourthly, the APA, with its judicial review provisions, was passed against the background of activist judicial review in constitutional law. Expectations about judicial review in administrative law were coloured by previous experience of judicial activism in constitutional law. If the Union were now to acquire an APA with judicial review, that review would no longer be seen only in the context of the rather modest review practices of European national administrative law but also in the context of the greater judicial activism of post-World War II national constitutional courts and of the Court of Justice itself ${ }^{13}$.

${ }^{13}$ Recent tendencies in European judicial review are examined in 'The Judicialization of Politics' issue of the International Political Science Review, vol 15, no 2 (April 1994), and in 'The New Constitutional Politics of Europe' issue of Comparative Political Studies, vol 26, no 3 (1994). 
A related point may be made about institutions. The APA choice of review in the regular courts rather than special administrative courts was inevitable given the American tradition. Whether the codified administrative law of the Union should be accompanied by the creation of separate administrative courts or, as with the uncodified administrative law of the Union, come under the Court of Justice and the Court of First Instance, is presumably an open question. It is an open question, however, precisely because the Union, like the US, now has a unified court system in which administrative law matters are the province of the 'regular' courts. The legal context of Union codification is now much more like the American context than it would have been had an administrative code been considered in the earliest days of the Community.

Finally, European and American experience converge on a dimension that I did not discuss much in my account of American developments. In the US, administrative law has always been entangled with the politics of regulation. The origin of the APA was in opposition to the regulatory enthusiasm of the New Deal. Its judicial review provisions were its key anti-regulatory feature, although judicial review was so entrenched in American legal experience that pro-regulatory forces could hardly oppose review. The key pro-regulatory features of the APA lie in the distinction between adjudication and rule-making and in what the APA does not require for rulemaking. The rule-making provisions do not require that there be a record in a rulemaking proceeding or that the agency demonstrate that its rule has an adequate basis in fact and logic. And then the APA resorts to the least demanding judicial review standard known to the American legal tradition, the arbitrary and capricious standard. If a reviewing court had before it no record of the facts and inferences on which an agency based its rule, how could that court ever do anything but what courts actually did do in the 1940s and '50s; assume that the agency had the facts and analysis to support its rule. If such an assumption is made, then the rule can hardly be said to be arbitrary and capricious. If a court has nothing to review, then its formal power to review is rendered nugatory. When the courts of the ' 60 s and ' 70 s began requiring agencies to compile a rule-making record, write a reasoned elaboration of their rule rather than a concise and general statement, demonstrate that they had given reasons for rejecting each of the points raised against the rule and considered all alternatives, the courts 'boot strapped' themselves into more active review. They forced the agencies to create a huge paper trail for every rule made. Free to roam along that paper trail, the judges could always find some impermissible gap in it if they wanted to.

It might be assumed that this rapid increase in judicial review favoured and was favoured by the anti-regulatory forces that had pushed the APA in the ' 30 s and ' 40 s precisely because it would provide judicial restraints on bureaucratic discretion. In the changed situation of the ' $60 \mathrm{~s}$, '70s and ' $80 \mathrm{~s}$, however, both pro- and anti-regulatory forces were attracted by review. Indeed pro-regulatory environmental groups were among the most active and successful invokers of review of rule-making and were largely responsible for pushing the courts into the great transformation of the administrative law of rule-making that occurred. As we have already seen, the wave of American health, safety and environmental regulatory statutes of the ' $60 \mathrm{~s}$, '70s and ' 80 s were enacted in a climate of suspicion of bureaucratic technocracy and so contained many 'agency forcing' and 'technology forcing' provisions. The judicial review provisions of these statutes were envisaged as providing opportunities to goad a sluggish and reluctant bureaucracy into living up to the great ambitions of the 
statutes. Of course anti-regulatory forces, essentially the regulated industries, used review to block or at least slow down what they viewed as overzealous new agency rules. Unlike the 1930s and ' $40 \mathrm{~s}$, in the ' 60 s and '70s judicial review was not a bone of contention between pro- and anti-regulatory forces. Both sides vigorously employed review.

Only in the 1980 s did this situation change. By then a host of health, safety and environmental statutes calling for high levels of regulation were in place. By then many federal regulatory agencies had come to be dominated by technocrats favouring high levels of regulation. Judicial review was still often used to push the agencies into higher levels of regulation. Those favouring regulation, however, were now often in the position of having won in Congress and won in staffing the agencies but seeing victories in policy implementation long delayed because of rigorous judicial review of rules. In recent years it has been American pro-regulatory forces that have been interested in developing quicker alternatives to rule-making.

The particulars may be different in Europe but the general entanglement of administrative law and regulatory politics is the same. The histories of the national administrative laws of Europe were largely driven by two basic concerns, the internal needs of the bureaucracy to discipline itself and a concern to protect individual property rights against arbitrary government incursions. The question of an administrative law for the European Union arises in the very specific context of the movement of regulatory regimes from national capitals to Brussels. Interest in codification, in 'independent agencies', etc. is not purely academic. It is not simply a matter of 'Now that we have the Union, of course we must have an administrative law for it just as we do for the nation-states.' Some academics may naively view what they are doing as an exercise in comparative administrative law that is designed simply to fill a gap in the legal regime of the Union as if the task of law professors, like mountain climbers, is to respond to a challenge just 'because it is there'. But what really pushes concerns to develop an administrative law for the Union is regulatory politics. The origins of the European Community certainly do not lie in deregulatory motivations per se. But deregulation has certainly been a major motivation of the Single Act ${ }^{14}$. And suspicion of Brussels regulators has certainly been central to the Maastricht and post-Maastricht controversies. It is not a coincidence, or a mere next step in the building process, that European lawyers are now so concerned about Union administrative law. Nor is it merely scholarly curiosity that has led Europeans to their recent interest in American administrative law which has as its principal theme judicial restraints on bureaucratic technocracy. The shift of regulation to Brussels at the very time that free-market ideology and the globalisation of markets makes regulation itself problematic is the context of European concerns with making an administrative law for the Union. It is that context that inspires European interest in American experience. It is that context that necessarily will determine European developments. As in the US, the new administrative law for the European Union is very much about the location and intensity of regulatory authority.

My general line of argument now runs as follows. Certain forces that operated more strongly and earlier in the United States are now growing in Europe. These include

\footnotetext{
${ }^{14}$ See Dehousse, 'The Institutional Dimension of the Internal Market Programme' (European University Institute, 1989); Shapiro, 'Federalism, Free Movement and the Regulation-Averse Entrepreneur', in H. Scheiber (ed), North American and Comparative Federalism (University of California, Berkeley Institute of Governmental Studies Press, 1992).
} 
constitutional judicial review, conflicting regulatory and deregulatory sentiments, fear of technology and technocracy and, most importantly, calls for transparency and public participation in the policy-making process. Resting on this parallelism alone, one would expect to see European administrative law now moving in the direction of more active judicial review just as that of the US did earlier. As in the US such 'metaprocedural' judicial review would allow European Union judges to avoid direct confrontation on substantive policy issues with other organs of government while also increasing their influence in the policy process. Because they are not entangled in partisan two-party politics as they were in the United States, however, such changes in European administrative law may well be less abrupt than they were in the US. The direction of European change is easier to predict than the speed of change.

A second and reinforcing element exists in this argument. The Union faces the 'American' forces faced by Europe in general but experiences them more strongly for a number of reasons. Regulation versus deregulation is even more central to the politics of the Union than to the politics of each of its Member States. The movement of regulatory authority from Member State capitals to Brussels accelerates the fear of technocracy and the desire for transparency and participation both among the people and the national economic elites. The key lies in the elites. Accustomed to a style of national regulation in which business elites and government technocrats formed an intimate 'in group' which negotiated mutually satisfactory regulatory compromises, the regulated firms now face a more distanced, less intimate regulation from Brussels in which national business leaders are less 'in'. If you are 'in', you do not concern yourself with participation and transparency, that is to the interests of the 'outs'. Indeed you are likely to oppose them. But if you are beginning to feel 'out', participation and transparency suddenly seem more attractive. Just as the regulated elites now support a large lobbying industry in Brussels ${ }^{15}$ (if you are 'in' you do your own lobbying - if you are 'out' you have to pay someone else to do it), they are likely to support an administrative law that opens up regulatory decision-making to outside influences.

Moreover, it is far easier to push for an American style 'reformation' of administrative law in the context of the Union than in national contexts because at the Union level we are doing 'formation' not 'reformation'. Unlike its Member States, the Union has no great weight of administrative law tradition that it must lever to a new position. To be sure, it must, of necessity, work with the materials of the national traditions, but it is clearly a new law that must be created for a new set of institutions beyond traditional conceptions of the 'state'.

Indeed it is the novel institutional arrangements of the Union as much as its distance and its newness that provide an especially fertile field for Americanisation. The Union has a single court system doing constitutional, administrative and 'regular' court work. On the one hand, the two Union courts do not experience the intimate alliance between administration and reviewer of administration that characterises judicial systems in which there are separate administrative courts. On the other, the Court of Justice does enjoy that extra surge of self-confidence that comes from being a successful constitutional court.

The effects of this unified jurisdiction are magnified by the unified nature of Union law itself. Whenever the Court of Justice, or for that matter the Court of First Instance, hears a challenge to a Commission action, it is operating simultaneously in

${ }^{15}$ S. Mazey and J. Richardson (eds), Lobbying in the European Community (Oxford, 1993). 
constitutional and administrative law. All this is not to deny that a careful distinction between administrative law and constitutional law could now be introduced into Union law, and a special place afforded to 'supplementary legislation' by the Commission or the comitology process. It is to say that because all norms enacted by the Commission or Council are subject to judicial review to determine whether they are in accord with the 'constitution' of the Union, the Court of Justice is engaged in validating or invalidating whole Commission regulations, not simply their particular applications and, as with the US Supreme Court, is likely to find analogies between its already well-established activist constitutional review and its growing administrative review.

This phenomenon is most clearly seen in one of the few, firm, existing bits of Union administrative law, the giving reasons requirement. The giving reasons requirement of Article 190 makes no distinction between primary and supplementary legislation or between Commission and Council enactments. When the Court of Justice voids some Commission decision because adequate reasons were not given, no distinction is, therefore, made between administrative and constitutional law. The decision, no matter how particular or how general, is void both as a decision and in its particular application. The giving reasons requirement is part of Union administrative law. It is also a constitutional rule that can be employed by the Court to invalidate any Union action from the broadest statute to the narrowest, individual application.

\section{Article 190 as a Test of Convergence}

Precisely because of these features of Article 190 it seems like an interesting laboratory for some quasi-experimental validation of the hypothesis I am offering here. The general hypothesis is, of course, that Union administrative law is likely to move in the directions that American administrative law did in the 1960s, '70s and '80s because it is now subject to the same forces that American law was then. The APA of 1946 contained a general giving reasons requirement, the provision for a concise and general statement of basis and purpose to accompany a rule. The particular hypothesis to be tested then runs as follows: Given that the American reasons requirement was initially very undemanding but eventually yielded an extremely activist judicial review that made great demands for participation and transparency on the rule-making agencies, we should expect Union courts to grow more activist in enforcing Article 190 on Union decision-making.

I have run this 'experiment' with, I believe, some success in confirming the hypothesis. The experiment and its results are reported elsewhere ${ }^{16}$. Briefly, it predicts that the Court of Justice will diverge from its long-held precedents and impose more demanding giving reasons requirements on the Commission. Between the time the paper was originally written and its publication, both the Court of Justice and the Court of First Instance issued opinions of a more or less American 'dialogue' style. They required that Union organs respond more completely to points made by those opposing a proposed action than the judges had previously required Union organs to do. It is particularly noteworthy that in doing so the Court of Justice came as close as a civil law court ever does to openly reversing a long-standing line of cases. Of course,

${ }^{16}$ Shapiro, 'The Giving Reasons Requirement in European Community Law', (1992) University of Chicago Legal Forum 179-220. 
in the nature of things, the experiment is hardly conclusive. As always with new case doctrine, it remains to be seen whether these cases are real turning points or mere aberrations. Certainly neither court has moved all the way to the American position that the agency must respond to every point raised by every interested party. But both courts do seem to be saying that they will exercise an independent judgment about whether Community organs have been transparent enough and responsive enough to outside participation. In any event, the experiment seems to have been successful enough to justify continuing to pursue the hypothesis.

\section{An Addendum on Supplementary Legislation}

If I may return to a point I made initially, from the American perspective European administrative law has been pretty much an uninteresting side-show devoted to making sure that the army of bureaucrats dresses its ranks properly and keeps its equipment clean. The real action in American administrative law lies in judicial supervision not of the details of implementation but of major technocratic policymaking through supplementary law-making. It is judicial review of the rules themselves, often in pre-enforcement review proceedings, not the review of particular applications, that expresses American energies. And so for Americans the most interesting question of codification of Union administrative law is whether the unique legal and institutional situation of the Union can or should lead to active judicial review of the rules and regulations engendered by the administrative organ of the Union, the Commission, whether such review is labelled administrative or constitutional or not labelled at all.

Does the urge toward codification provide the occasion for working out institutions, procedures and doctrines of supplementary law-making and judicial review of such law-making for the Union? The most obvious answer is that the Union already has a far better way of checking technocratic policy-making than a system of supplementary law-making subject to judicial review. Every Commission initiative is supervised by the Council and cannot become legally binding until the Council enacts that initiative as law. The Council does better than delegating its legislative powers and then depending on the courts to ensure that those engaged in delegated legislation follow the will of the delegator. Instead the Council does not delegate its law-making powers but exercises all its legislative powers itself. No principal agent problem arises because the principal retains all power himself.

Two real world phenomena interfere with this picture of non-delegation. Both are related to the increasing volume of Commission responsibilities as the web of Union regulation becomes more and more fine-spun. As Commission initiatives increase in number and in technical detail, Council 'enactment' becomes more and more either a fiction or another episode of technocracy. That is, either the actual political members of the Council come to rubber stamp the flow of Commission initiatives they cannot understand or keep up with or the Council sets its own technocratic staff to check on the Commission technocrats. Either way, popular or lay control over technocrats tends to be eroded. Secondly, the volume of regulatory decisions tends to get so high and so particularised that it is simply impossible for the Council to enact them all. The Commission begins to invent ways of announcing regulatory policies that effectively constrain the regulated but do not require Council enactment. Where the Commission carefully crafts a stable pattern of 'administrative' implementations, that pattern may constitute a new or modified rule but not one that the Council need enact. 
That the Union has now entered the stage at which large amounts of sub-legislation will be necessary is shown by the new process in which the Council does delegate supplementary law-making authority to the comitology process. While in theory each piece of delegated comitological rule-making must subsequently be approved by the Council, it remains to be seen whether this formal mechanism will really work.

A codification project for the Union seems an appropriate occasion for considering whether the Union ought to establish a formal system of supplementary or delegated legislation with or without judicial or some other sort of review to deal with the problem of whether the delegatee is acting lawfully under the delegating legislation.

\section{Conclusion}

Thus, from the American perspective, a debate about the codification of Union administrative law will be something more than an episode of the compulsive neatness for which European legal scholarship is famous. Such a debate will necessarily be about levels of judicial supervision of technocratic government and levels of transparency and outside participation in bureaucratic decision-making. Such a debate is both engendered by forces previously felt in the US and should be informed by American experience with what began as a pro- and anti-regulation compromise and grew into a largely new and unanticipated administrative law that maximised participation, transparency and judicial supervision of key administrative action.

In general then American experience suggests two basic, inter-related problems worth considering for those concerned with the codification of Union administrative law. The first is the general intensity of judicial review. To what extent is it possible, inevitable or desirable that judicial review of administration become a vehicle for the introduction of more elements of democratic transparency and participation into bureaucratic, technocratic decision-making? Secondly, should administrative law be written small or large? That is, should administrative law and judicial review stick to questions of whether a rule has been properly applied in a particular instance? Or should administrative law and judicial review, whether under the 'constitutional' guise of enforcing Article 190 and others on the Commission, or the more purely administrative law guise of an acknowledged system of delegated legislation, also consider whether the rules themselves are lawful?

The more Union codification programmes address themselves to the question of judicial power to invalidate rules the more interesting they become to Americans and, far more importantly, the more relevant they become to the major institutional and policy concerns of the Union. The more such programmes confine themselves to judicial invalidation of particularised implementations of rules, the more they become purely academic exercises in comparative law. If this latter approach is taken, then the real action will occur not in something labelled 'administrative law' but in something labelled 'constitutional law', defined as encompassing the power of Union courts to invalidate Union rules on the grounds that they are in conflict with the treaties or constitutional instruments of the Union.

\section{Bibliography}

'The New Constitutional Politics of Europe', (1994) Comparative Political Studies, vol 26, no 3 K. C. Davis, Administrative Law Treatise (multiple volumes, frequently supplemented) 
Dehousse, 'The Institutional Dimension of the Internal Market Programme', European University Institute, 1989

A. V. Dicey, Introduction to the Law of the Constitution (Macmillan, 4th ed, 1893)

C. Edley, Administrative Law: Rethinking Administrative Control of Bureaucracy (Harvard University Press, 1990)

'The Judicialization of Politics', (1994) International Political Science Review, vol 15, no 2

S. Mazey and J. Richardson (eds), Lobbying in the European Community (Oxford, 1993)

G. Robinson, E. Gellhorn and H. Bruff, Administrative Law (West Publishing Co., periodic new editions, annual supplements)

P. Schuck, Foundations of Administrative Law (Oxford, 1994)

B. Schwartz, Administrative Law (Little Brown, periodic new editions and supplements)

J. Schwarze, European Administrative Law (Sweet and Maxwell, 1992)

Shapiro, 'Judicial Activism', in S. M. Lipset (ed), The Third Century (Hoover Institution Press, 1979)

M. Shapiro, Who Guards the Guardians (University of Georgia Press, 1988)

Shapiro, 'Federalism, Free Movement and the Regulation-Averse Entrepreneur', in H. Scheiber (ed), North American and Comparative Federalism (University of California, Berkeley Institute of Governmental Studies Press, 1992)

Shapiro, 'The Giving Reasons Requirement in European Community Law', (1992) University of Chicago Legal Forum 179

Stewart, 'The Reformation of American Administrative Law', (1975) 88 Harvard Law Rev. 1667

G. Teubner and A. Febbrajo (eds) State, Law and Economy As Autopoietic Systems: European Yearbook of the Sociology of Law (Guiffre, 1991-92)

'The Administrative Procedures Act: A Fortieth Anniversary Symposium', (1986) Virginia Law Review, vol 72 